UDC 2-1

Andranik STEPANYAN

\title{
CRITICAL REMARKS ON THE ESSENCE AND SCOPE OF PHILOSOPHY OF RELIGION
}

\begin{abstract}
The goal of this article is to critically examine the essence and scope of philosophy of religion, its place and relation to philosophy and religious studies. The philosophy of religion is interrelated with philosophy and religious studies and is an interdisciplinary field of study. Being an inter-disciplinary field on the boundary of philosophy and religious studies and as a phenomenon of western rationalistic tradition philosophy of religion is engaged in conceptual and theoretical examination and analysis of the content of religion. Philosophical reflections on religious matters, concepts, claims and practices, the origin of religion, the relation between religion and other fields of knowledge and culture, and so on, are the scope of philosophy of religion. It is based on a rational approach. One of the functions of philosophy of religion is to verify from the standpoint of logic whether the religious or theological claims and statements are trustworthy and rational, true or false. From this viewpoint, philosophy of religion ought to be, to some extent, a normative discipline, a feature that has been overlooked by many scholars and philosophers of religion. The aim of this discipline is the philosophical examination and understanding of the phenomenon and essence of religion.
\end{abstract}

Keywords: philosophy of religion, religious philosophy, theology, philosophical theology, natural theology, religious metaphysics, philosophy, religious studies, the phenomenon of religion, the essence of religion.

Introduction

In the history of mankind religion as a social phenomenon, has almost always accompanied it through the stages of human development by having had, to some extent, its positive and negative influence on the awareness of a society and an individual. Religion as a type of spiritual activity, has taken a part of the culture of different groups, ethnic-national units and humanity in general. Religion is a complex and rich human phenomenon which has been studied by different thought systems, conceptual models, methodological approaches and fields of knowledge that seek to grasp and comprehend the religious phenomenon.

In contemporary religious studies (from theoretical and historical standpoint) there are many theoretical and methodological approaches concerning the origin of religion as a phenomenon, definition of the concept of religion, by which scholars, from different fields of knowledge and expertise, attempt to explore and understand the essence and/or nature of religion. 
The differences in "theories and methods are conditioned by scholars' world view orientation and methodological approaches which impact on the body, nature and features of knowledge and research in religious studies and outline academic attitude regarding the phenomenon of religion and future development of religious studies" (Stepanyan, 2012, p. 230) as a multi-disciplinary system of knowledge.

In the contemporary study of religion, there are major conceptual models to understanding and interpretation of religion: philosophical, theological (denominational), sociological, psychological-cognitive, biological, anthropological. Every conceptual system has its own premises, methodological principles and approaches which distinguishes one from another but all conceptual systems are interrelated and interact with one another. The following branches of contemporary religious study are philosophy of religion ${ }^{1}$; sociology of religion; psychology of religion; cognitive studies in religion (still becoming); history of religion; phenomenology of religion; anthropology of religion.

The philosophy of religion is one of the above-mentioned conceptual models or fields of knowledge that examines religion. The goal of this article is to investigate the essence and scope of the philosophy of religion, its role and place in relation to philosophy and religious studies.

The occurrence of "Critical Remarks" in the title of my article is not occasional. This is my second article, which starts with "Critical Remarks". In my first article (See Stepanyan,

\footnotetext{
It is noteworthy to mention that many scholars of religion and academic schools do not consider philosophy of religion as a branch of religious studies (See Shakhnovich, 2015, p. 9). Nevertheless, the author considers this viewpoint as groundless and counts the philosophy of religion as a branch of religious studies as well as philosophy.
}

2017), I have critically examined Vahanian's death of God theology. Hence, the appearing of "Critical Remarks" in the title of the article shows my intention to critically examine and analyze the issues and matters. So I believe that this critical mood and intention will be continued in my future research.

$$
\begin{gathered}
\text { Philosophy, Religion and Religious } \\
\text { Studies }
\end{gathered}
$$

What is the philosophy of religion? Why one has to study religion philosophically? Where does philosophy of religion stand? These are just a few questions that arise concerning the philosophy of religion.

Philosophical reflection on religious matters is almost as old as the philosophy itself. Historically the roots of philosophy of religion go to ancient Greek philosophy, namely Plato and Aristotle but Hegel (1988) seems to be the first that used the term 'philosophy of religion' as the title of his book demonstrates. Therefore, this intellectual enterprise is not new in contemporary academic study. How should philosophy of religion be understood? First, one deals with two terms: philosophy and religion. The proper way to understand the philosophy of religion is to comprehend the meaning of these two words. The word philosophy in Greek means 'love of wisdom.' Here are a few generally accepted definitions of philosophy. Philosophy is the study of general and fundamental questions about existence, knowledge, values, reason, mind, language, etc. Philosophy is a conceptual comprehension of the world; it is the knowledge of the general taken as a whole. From this point of view, philosophy is the integrated whole that consists of rational, conceptual-theoretical and worldviewaxiological components. 
Next important thing that needs to be clarified is religion. What is religion? There is no generally accepted definition concerning religion. There are a number of definitions of religion, but the aim of this article is not to study it deeply. Nevertheless, as Chad Meister rightly said "attempting to offer a definition of religion which captures all and only what are taken to be religions is notoriously difficult. Central to some religions is a personal God and other spiritual entities; for other religions, there is no God or spirits at all. Some religions view the eternal, personal existence of the individual in an afterlife as paramount to understanding Ultimate Reality and much more important than temporary earthly existence. Others see what we do in this life as fundamental, with little if any consideration of the hereafter. Other differences among the religions abound. But as diverse as religions are, several components seem to be central to the world religions: a system of beliefs, the breaking in of a transcendent reality, and human attitudes of ultimate concern, meaning, and purpose. Given these three elements, the following perhaps captures what most take to be the essence of the concept of religion: a religion involves a system of beliefs and practices primarily centred around a transcendent Reality, either personal or impersonal, which provides ultimate meaning and purpose to life" (Meister, 2009, p. 6). I think these three components described by Meister are acceptable if not by all but at least by many scholars of religion as a general definition of religion.

Secondly, as far as the philosophy of religion is philosophy then it belongs to philosophy; it is a part and field or branch of philosophy in the same way, and similar as a philosophy of science is to science, philosophy of law is to law, philosophy of art is to art and so on. At the same time, it is the philosophy of religion, which means that it also belongs to religion, namely, to the sphere of study of religion, hence religious studies. Accordingly, philosophy of religion is interrelated to both philosophy and religious studies. This is the reason why the author does not accept the position of some scholars of religion, academic schools and philosophers who claim that as far as it is philosophy of religion then it only belongs to philosophy but when it comes to sociology of religion, psychology of religion or history of religion, etc. it is accepted that these inter-disciplinary fields of knowledge belong to or are parts of religious study. Consequently, philosophy of religion is not only interrelated to both philosophy and religious studies, but it is an interdisciplinary field of knowledge. At last but not least, we have religious studies. What are religious studies or science of religion? I would like to offer two definitions of religious studies which, I do hope, will thoroughly explain what religious studies is all about. Accordingly, "Religious studies represent ... a scientific interdisciplinary field that investigates the phenomenon of religion, religious beliefs and perceptions, religious consciousness and experience, religious institutions. It describes, compares, classifies and explains the religion in its totality and diversity. Religious studies are systematic; it is based on historical reality and has inter-cultural directness" (Vermishyan \& Stepanyan, 2015, p. 105). The second definition, though it differs from the first one but is very important because it discovers another dimension of this field of knowledge: "Religious studies are a relatively self-reliant comprehensive field of knowledge. ... Religious studies investigate the laws of origin, development and functioning of religion, its structure and different components, its diverse phenomena as they had appeared in the history of society, its 
interrelation and interaction with different branches of culture" (Yablokov, 2004, p. 5).

Indeed, philosophy of religion can be "the relevant section" as for philosophy so for religious studies. Of course, as it is rightly said: "the status and relations of the philosophy of religion in philosophy and religious studies are not the same" (Yablokov, 2016, p. 82) and it is impossible to be the same due to the characteristics and subject matters of both disciplines. In philosophy "the integrating" sections are metaphysics, ontology, gnoseology (epistemology), social philosophy and the philosophy of religion interacts with them as well as with logic, ethics, aesthetics and other philosophical sections and disciplines. In religious studies "the philosophy of religion is itself the integrating" component and is tied to sociology, psychology, phenomenology, history of religion and other sections and disciplines. Here "the philosophy of religion puts together multi-levelled and diverse knowledge about religion in a system and plays appropriate methodological function" (Yablokov, 2016, pp. 82-83).

\section{The Essence of Philosophy of Religion}

As far as we have given definitions and conceptual clarifications regarding the terms, namely, philosophy, religion and religious studies, we can move to the next step: what philosophy of religion is all about. The essence or nature and scope of philosophy of religion is a topic that has been discussed by many authors, and we will go through some of them in order to understand it. In academic literature, there is a controversial situation among scholars and philosophers of religion concerning what philosophy of religion is supposed to be.

During its history, philosophy made religion the object of its scrutiny and comprehension.
There are many approaches and viewpoints in the philosophy of religion. Actually, the differences behind them depend on each individual philosopher. Historically, all philosophers (Spinoza, Hume, Kant, Hegel, Marx, Engels, Feuerbach and etc.) who studied or had contemplation on religion had used different premises and methods for making religion the subject matter and object of their philosophical inquiry. However, what is common among them is that all of them studied and analyzed religion philosophically, from a philosophical point of view. The essential attribute of the philosophical methodology is "universality and substantiality" (Radugin, 2001, p. 13). Philosophy attempts to comprehend or "explain all phenomena and processes of the reality from the viewpoint of its general laws and principles by determining the 'essence' of entities, processes and phenomena" (Radugin, 2001, p. 13). Philosophy applies the critical approach for all the phenomena of reality, including religion. Philosophy in contrary to theology, which is based on faith and revelation, doubts and questions everything. Philosophy suspects in order to verify and make sure whether the claims and statements are trustworthy and rational.

A theological approach to religion is 'inner' as far as it attempts to understand and explain religion, religious claims, concepts and perceptions from within and from the position of religious ideology (Stepanyan, 2012, p. 231) and interpret it for its own community of believers. As opposed to theology, philosophy of religion analyzes religion in general and approaches religion from external, 'outside,' from unbiased, unprejudiced and objective position and standpoint. The philosophy of religion ought to be neutral as far as possible. And above all, the philosophy of religion is to be non-religious. The methodology of philosophy of religion differs 
from a theological approach. If "theological methods and approaches act in the framework of religious experience based on religious ideology and doctrines taken as the premise and absolute truth then philosophical methodology requires to come out of the framework of that experience and study and learn religion critically" (Stepanyan, 2012, p. 233), that is using rational thinking and critical reasoning as basis of its methodology.

The problem in contemporary philosophy of religion is that there is no current consensus on precise identification of what counts as a philosophy of religion. The situation is more complicated due to the following reasons: 1 . There are many religions like Judaism, Buddhism, Christianity, Hinduism, Islam and etc. And the question rightly arising is the philosophy of which religion. Then it is understandable what the outcome will be. 2 . As far as the philosophy of religion is the phenomenon of western rationalistic tradition, there are different worldview orientations within the philosophy of religion: theism, pantheism, deism, atheism, agnosticism, secularism and etc. Also, there are many schools and thought systems in philosophy with different approaches: positivism, Marxism, pragmatism, analytic philosophy, phenomenology, existentialism and etc. 3. There are a few terms which have an almost similar meaning, or the distinction is not so big between them: philosophy of religion, religious philosophy, religious metaphysics, philosophical theology, natural theology. As a result of that, there can be confusion of how to understand, define and differentiate them. 4. Finally, the identification of philosophy of religion, what it ought to be, what the nature of the philosophy of religion is.

If we have a look at some definitions of the philosophy of religion, we can see that there are two major types for understanding what philosophy of religion is. The mainstream types, according to the definition of and what is meant by the philosophy of religion, are a. rational defence of religion, b. philosophical reflection or contemplation on religious matters and issues. In this article, we will review some definitions of the philosophy of religion offered by Englishspeaking and Russian scholars and philosophers.

Some scholars or thinkers have defined the philosophy of religion as the rational defence of religion. According to John Hospers (1997), philosophy of religion is concerned, as philosophy always is, with the justification of belief. By what arguments, if any, can a religious belief be defended or attacked? (p. 201). Wayne Proudfoot (1987) defines the philosophy of religion as the philosophical scrutiny of religion and gives it two main tasks: 1 . assessment of the rationality of religious beliefs with some attention to their coherence and to the cogency of arguments for their justification; and 2. the descriptive analysis and elucidation of religious language, belief and practice with particular attention to the rules by which they are governed, and to their context in the religious life (p. 305). Philosophy of religion, according to D. S. Adam (2003), "is the highest stage or form of theology" (p. 299). If one looks at the philosophy of religion from this viewpoint then, of course, the philosophy of religion is almost identical or similar to systematic theology or philosophical theology, or it is as Adam rightly says "the highest stage or form of theology".

Unfortunately, if one surveys many books, companions or guidebooks on the philosophy of religion, then one can see that many of them are either systematic theology or some form of theology books. But the philosophy of religion is to be distinguished from all of them - philosophical theology, systematic theology, apologetics and 
even religious philosophy. As P. Helm (1991) rightly says "Unlike philosophical theology, which is concerned with ontological and logical reflection on the doctrine of God (and which has as a matter of historical fact been closely tied to the Judaeo-Christian tradition), the philosophy of religion is concerned with religion as a pervasive feature of human culture. And unlike the apologist, the aim of the philosopher of religion is to understand and evaluate religion from a philosophical standpoint rather than to defend religion, or a particular religion, by philosophical argument" (p. 513). Therefore, the philosophy of religion is not and can not be the rational defence of religion. The author does not support this view on the philosophy of religion. This is not the right way to understand the philosophy of religion.

Contrary to the first viewpoint, the author is in favour of the second one; that is the philosophy of religion is philosophical reflection or contemplation on religious matters and issues. Now we will look at some contemporary definitions of the philosophy of religion in the framework of the second viewpoint offered by Englishspeaking and Russian thinkers and philosophers, which, in my opinion, are noteworthy and correctly express the identification and meaning of the philosophy of religion as an intellectual enterprise. According to John Hick (1990), "The name "philosophy of religion" for what (by analogy with the philosophy of science, philosophy of art, etc.) is its proper meaning, namely, philosophical thinking about religion" (p. 1). For Michael Peterson et al. (1991) "Philosophy of religion is the attempt to analyze and critically evaluate religious beliefs" (p. 8). Charles Taliaferro (2003) writes that "Philosophy of religion explores philosophical issues that arise from reflection on the nature and truth of religious belief and the meaning of religious practices.... The field includes philosophical arguments for and against belief in a Creator of the cosmos, comparative treatments of the Divine, accounts of the meaning of religious language and faith, the ethical implications of religious commitments, the relation between faith, reason, experience and tradition, concepts of the miraculous, the afterlife, the sacred revelation, mysticism, prayer, salvation and other religious concerns" (p. 453). In his another article Charles Taliaferro (2019) says that "Philosophy of religion is the philosophical examination of the themes and concepts involved in religious traditions as well as the broader philosophical task of reflecting on matters of religious significance including the nature of religion itself, alternative concepts of God or ultimate reality, and the religious significance of general features of the cosmos (e.g., the laws of nature, the emergence of consciousness) and of historical events (e.g., the 1755 Lisbon Earthquake, the Holocaust)". According to C. Stephen Evans (1982), philosophy of religion is "critical reflection on religious beliefs" (p. 11).

Russian philosopher D. V. Pivovarov (2006) writes that there are three main forms of the philosophy of religion: 1 . Philosophy of religion understood as the totality of worldview ideas existing within a given religious system, for example, Buddhism; 2. Philosophy of religion as a part of a given philosophical system, for example, the philosophy of religion in the philosophical system of Hegel; 3. Philosophy of religion understood as a relatively self-reliant philosophical discipline like the philosophy of science, philosophy of law and etc. which has divisions like metaphysics of religion, gnoseology of religion, logic of religion. However, Pivovarov is in favour of the third form of philosophy of religion, the subject matter of which is man's religious 
attitude to the world and his relation to the absolute (pp. 8-9). For P. S. Gurevich (2007) "Philosophy of religion is the totality of philosophical presuppositions in relation to religion, philosophical comprehension of its nature and functions, as well as philosophical justification of the deity, discussions on his nature and his relation to the world and human being" (p. 27).

In the book Philosophy of Religion written by a group of Russian philosophers "The philosophy of religion counts or represents by itself as philosophical comprehension of the essence of religion. The philosophy of religion by studying varied religious forms defines what religion is all about in general, what is its content, what are the functions of religion, what role it has in the history and in the life of a man. Philosophy of religion not only attempts to discover the forces of the origin of religion but studies the questions concerning the origin of the idea of God and the possibilities of the evidence of God's existence. It investigates the nature of religious faith and consciousness, relations between religion and science, religion and art and, characteristics of religious language" (Shakhnovich, 2015, p. 11). According to the book Religious Studies, "Philosophy of religion is the totality of philosophical concepts, ideas, notions, principles, methods through which philosophical explanation and understanding of the object are given" (Yablokov, 2016, p. 83). So understood the philosophy of religion is "specific philosophical discipline" which applies philosophical knowledge, gained from metaphysics, ontology, gnoseology (epistemology) and other philosophical disciplines, to the analysis of religion (Yablokov, 2016, p. 83).

According to Russian philosopher Yu. A. Kimelev, the philosophy of religion is divided into two parts: philosophical religious studies and philosophical theology. Philosophical religious studies are "the totality of philosophical reasoning the subject of which is man's 'religious attitude' or man's 'religious consciousness" (Kimelev, 1998, p. 12). The purpose of philosophical theology is "to create the doctrine of God through philosophical means only" (Kimelev, 1998, p. 16). In a different way, we can affirm that philosophical theology builds or creates religious doctrines through philosophical concepts, notions, categories and means. Here the philosophical theology is identical to or like natural theology, religious philosophy, Christian philosophy, religious metaphysics or rational theology. All these names are synonyms because all of them are religious-philosophical forms of theorization on religious topics, matters and issues from the standpoint of religious ideology.

Based on the above-mentioned definitions of the philosophy of religion, of course, in the framework of the second viewpoint, we can shortly affirm that the philosophy of religion is a philosophical reflection and/or contemplation on religious matters and issues.

One has to distinguish the philosophy of religion from religious philosophy. Religious philosophy is always based on a given religious ideology, doctrines and worldview orientation "which is closely linked to theology and uses philosophical concepts for religious comprehension of the world and philosophical reflection for interpretation of religious experience" (Shakhnovich, 2015, p. 10). Besides that, religious philosophy studies philosophical issues from the position and standpoint of religious ideology, doctrines, worldview and thinking. As Evans (1982) rightly puts down "As a form of reflection, philosophy is always self-conscious and critical. ... It is this critical and reflective side of philosophy that is more evident in the philosophy 
of religion" (p. 16). Therefore, contrary to religious philosophy, "philosophy of religion is not so much religious thinking as it is thinking about religion" (Evans, 1982, p. 16). The object of the study of philosophy of religion is man's religious attitude to the world and reality.

Philosophy of religion, by being an interdisciplinary field on the boundary of philosophy and religious studies and as a phenomenon of western rationalistic tradition, is engaged in conceptual and theoretical examination and analysis of the content of religion. Philosophy of religion is based on the rational principle and approach. One of the functions of philosophy of religion is to verify whether the religious or theological principles, claims and statements are trustworthy and rational, true or false, adequate or nonadequate from the standpoint of logic. Viewed from this position philosophy of religion is or ought to be, to some extent, a normative discipline, a feature that has been overlooked by many scholars and philosophers of religion. Usually, to many scholars and philosophers, the philosophy of religion is understood as a descriptive analysis of religious matters. This is the reason why we can see the lack of critical analysis in contemporary literature on philosophy of religion.

Therefore, "philosophy of religion is multifaceted, multifarious and comprehensive study of religion" (Stepanyan, 2012, p. 235) and from discipline standpoint philosophy of religion attempts to comprehend, explain and evaluate the phenomenon of religion, that is: religious matters, religious beliefs, religious concepts and claims, religious practices. After all, the philosophy of religion is a philosophical examination and comprehension of the phenomenon and essence of religion.

\section{The Scope of Philosophy of Religion}

Once we have clarified the essence and/or nature of the philosophy of religion now, we need to outline the scope and issues of philosophy of religion, which is very broad and diverse. It includes matters and issues that are beyond religion, but the subject matter of philosophy of religion is religion itself in a narrow sense. The scope of philosophy of religion varies due to the wide range of topics, themes, matters and issues that are included in religion like religious claims: for example, that God exists; religious concepts: omnipotence, omniscience, immutability, paradise, hell and, etc. and how one can interpret and understand these concepts, and religious practices: prayer, rituals, symbols and about which can be asked whether each one is sensible and if so what is the meaning of it. Besides that, there are different issues and matters like the origin of religion, what are human needs in religion and expectations from it, the relation between reason and revelation, the relation between science and religion, ethics and religion, culture and religion, religious language, religious pluralism and etc. One of the issues or matters that is of great importance for the philosophy of religion is to analyze the religious consciousness in its relation to the language of religion, religious beliefs and judgments.

Among the scope and issues of the philosophy of religion, the following considerations based on the book, Religious Studies are very important and noteworthy: 1 . To reveal the status of the philosophy of religion in philosophy, religious studies and other related fields of knowledge; to define specifics or characteristics of philosophical comprehension of religion and to solve the question of philosophical methods for 
understanding religion. 2. To consider the features and structure of the knowledge of religious studies, the laws of its development, the role and place of religious studies in the system of sciences. 3. To analyze different variants for the disclosure of the essence of religion, to find appropriate methods to define religion, to formulate the philosophical definition of the concept of religion. 4. To reveal the ontological foundations of religion and to analyze the gnoseological premises of religion. 5. To examine the characteristics of cognition processes in the religious consciousness. 6. To study the religious worldview and its different types, religious beliefs, concepts, perceptions, judgments, statements, the structure of inference or speculations, the language of religion, theistic doctrines of God and justification of his existence, and etc. 7. To reveal the content and specifics of religious philosophy - religious metaphysics and ontology, epistemology and anthropology, ethics, and etc. (Yablokov, 2016, pp. 83-84).

Accordingly, philosophical reflections on religious matters, ideas, concepts, claims and practices, the origin of religion, the relation between reason and revelation, the relation between religion and other fields of knowledge and culture; philosophical analysis of the religious consciousness, the religious language, and etc. are the scope of philosophy of religion. The subject matter of philosophy of religion is religion itself in its wholeness and totality.

\section{Conclusions}

Therefore, the philosophy of religion is not only interrelated to both philosophy and religious studies, but it is an interdisciplinary field of knowledge. Philosophy of religion is a multifaceted, multifarious and comprehensive study of religion, from discipline standpoint philosophy of religion attempts to comprehend, interpret and explain the phenomenon of religion, that is: religious matters, religious beliefs, religious concepts and claims, religious practices.

Philosophy of religion ought to be, to some extent, a normative discipline, a feature that has been overlooked by many scholars and philosophers of religion. For many scholars and philosophers, the philosophy of religion is understood as a descriptive analysis but not a critical analysis of religious matters.

Philosophy of religion studies and explains man's religious attitude to the world and reality. Hence, the philosophy of religion is a philosophical examination and comprehension of the phenomenon and essence of religion.

Philosophical reflections on religious matters, ideas, concepts, claims and practices, the origin of religion, the relation between religion and other fields of knowledge and culture; philosophical analysis of the religious consciousness, the language of religion, and so, on are the scope of philosophy of religion in a wide sense. Taken only in its wholeness and totality, religion is the scope or subject matter of philosophy of religion in a narrow sense.

\section{REFERENCES}

Adam, D. S., (2003). Theology. In J. Hastings (Ed.), Encyclopedia of Religion and Ethics (Vol. 12). London: T \& T Clark. Evans, C. S., (1982). Philosophy of Religion: Thinking About Faith. Downers Grove: InterVarsity Press.

Gurevich, P. S. (2007). Religiovedenie (Religious Studies, in Russian) (2nd ed.). Moscow-Voronezh: NPO MODEK.

Hegel, G. W. F. (1988). Lectures on the Philoso- 
phy of Religion. One-Volume Edition, The Lectures of 1827. Berkeley, Los Angeles, London: University of California Press.

Helm, P. (1991). Philosophy of Religion. In S. B.

Ferguson, D. F. Wright (Eds.), New Dictionary of Theology (pp. 513-515). Leicester: Inter-Varsity Press.

Hick, J., (1990). Philosophy of Religion (4th ed.). New Jersey: Prentice-Hall Inc.

Hospers, J., (1997). An Introduction to Philosophical Analysis (4th ed.). London: Routledge.

Kimelev, Yu. A. (1998). Filosofiya religii: Sistematicheskii Ocherk (Philosophy of Religion: Systematic Survey, in Russian). Moscow: Nota Bene.

Meister, C., (2009). Introducing Philosophy of Religion. London and New York: Routledge.

Peterson, M., Hasker, W., Reichenbach, B., \& Basinger, D. (1991). Reason and Religious Belief: An Introduction to the Philosophy of Religion. Oxford: Oxford University Press.

Pivovarov, D. V., (2006). Filosofiya religii (Philosophy of Religion, in Russian). Moscow: Academicheskii Proekt.

Proudfoot, W. (1987). Philosophy of Religion. In M. Eliade (Ed.), The Encyclopedia of Religion (Vol. 11, pp. 305-334). London \& New York: Macmillan Publishing Company.

Radugin, A. (2001). Vvedenie v religiovedenie (Introduction to Religious Studies, in Russian). Moscow: Centr.

Shakhnovich, M. M. (Ed.). (2015). Filosofiya religii (Philosophy of Religion, in Russian). Moscow: Yurait.

Stepanyan, A. (2017). Critical Remarks on the Theoretical Significance of Vahanian's Death of God Theology (Brief Review). WISDOM, 9(2), 56-66.

Stepanyan, A. (2012). Kroni astvac'abanakan ev pilisopayakan hayecakargeri y'ndhanur bnutagiry' (General Characterictics of Theological and Philosophical Concepts of Religion, in Armenian). Kantegh, 51(2), 230-235.

Taliaferro, Ch. (2003). Philosophy of Religion. In N. Bunnin \& E. P. Tsui-James (Eds.), The Blackwell Companion to Philosophy (pp. 453-489). (2nd ed.). Oxford: Blackwell Publishing.

Taliaferro, Ch. (2019, Spring). Philosophy of Religion. In E. N. Zalta (Ed.), The Stanford Encyclopedia of Philosophy. Retrieved March 28, 2019 from: https://plato.stanford.edu/archives/spr2 019/entries/philosophy-religion/.

Vermishyan, A., \& Stepanyan, A. (2015). “Kroni masin gitutyuny" ev kronagitutyuny vorpes inqnuruyn gitakarger (Science of Religion and Religious Studies as Self-Reliant Disciplines, in Armenian). WISDOM, 4(1), 97-108.

Yablokov, I. N. (Ed.). (2004). Osnovi religiovedeniya (Basics of Religious Studies, in Russian) (4th ed.). Moscow: Visshaya Shkola.

Yablokov, I. N. (Ed.). (2016). Religiovedenie (Religious Studies, in Russian). Moscow: Yurait. 